\title{
Factors Influencing Student Veteran Participation in Online Engineering Ed- ucation
}

\section{Dr. Douglas Moore Schutz, Tokyo University of Science}

Douglas M. Schutz is Vice President and Senior Business Analyst for a Fortune 500 bank where he turns data into knowledge. He recently was Associate Professor of Information Systems, International Business, and Management at the Tokyo University of Science in Japan. He received a Ph.D. in Business Administration focusing on Information Systems from the Fox School of Business of Temple University in Philadelphia, an MBA in Information Systems from the McCombs School of Business of the University of Texas at Austin, and a B.S. in Electrical Engineering from the United States Naval Academy at Annapolis focusing on digital design. He was one of $40 \mathrm{Ph}$.D. students selected globally to present his research at the International Conference on Information Systems (ICIS) Doctoral Consortium in Shanghai, China. His research has been nominated Best Paper at the Hawaii International Conference on Systems Science (HICSS), and his work has been published multiple times by the Japan Society of Information and Management (JSIM). He has been a guest lecturer at the Regensburg University of Applied Sciences in Germany and at the Vietnam National University in Hanoi. Prior to academia, He worked as an IT manager and consultant in the energy industry out of New Orleans, Louisiana for two Fortune 500 companies, where his responsibilities included IT disaster recovery from Hurricane Katrina. A U.S. Navy combat veteran, he served as an unrestricted line Surface Warfare Officer (SWO) on board a guided missile destroyer during the Cold War, and on the second Aegis cruiser during the Gulf War.

\section{Prof. Yong-Young Kim P.E., Konkuk University}

Yong-Young Kim is Associate Professor of Division of Business Administration and Economics at Konkuk University in Korea. He earned his Master's and Doctoral Degree in Management Information Systems from Seoul National University in Korea. His research interests include Smart Work, online games, IT experiential learning processes, and IT convergence \& platform. His papers have appeared in Information Resources Management Journal, Cluster Computing, International Journal of Advanced Media and Communication, Asia Pacific Journal of Information Systems, and Journal of Korean OR/MS Society and also have been presented at many leading international conferences (ICIS, HICSS, PACIS).

\section{Dr. Dante Dionne, Korean Air}

Dante Dionne is a Senior Innovation Technology consultant. The past 20+ years of his career has centered on management and professional services consulting. Where, he has specialized in leading multi-national project teams in digital business transformation, mobility and innovative technology solutions.

Dante received his Ph.D. in Psychology with a focus on Organizational Leadership and an MA in Industrial/Organizational Psychology from the Chicago School of Professional Psychology, and a BS in Business Management with a specialization in Computer Electronics. Dante has graduate level teaching credits in Psychometrics, Data Management and as a Visiting Scholar at the Tokyo University of Science and Vietnam National University. Dante's research spans several specializations in psychology including: Social, Cultural, Developmental, Cognitive, Performance, Sports, and Positive Psychology. Dante is also an active member of American Psychological Association (APA) Division 46 (Society for Media Psychology and Technology), Division 14 (Society for Industrial and Organizational Psychology), Division 13 (Society of Consulting Psychology) and Division 47 (Society for Sport, Exercise and Performance Psychology). 


\title{
Factors Influencing Student Veteran Participation in Online Engineering Education
}

\begin{abstract}
This study seeks to find out what influences student veteran enrollment in online engineering education. Engineering schools want to not only improve their graduation rates, they also want to attract greater student diversity. In this paper, we use student veterans as a proxy for diversity through their unique shared experiences, norms, and values acquired from training and service in the military of the United States. Previous research reveals that student veteran enrollment can benefit the graduation rates of engineering programs, as well as their diversity of knowledge. Diverse sources of knowledge provide multiple perspectives benefitting the learning process for students and professors alike. At the same time, emerging online learning platforms enable the interactive exchange of knowledge across time and space. Student veterans and active duty service members can now earn graduate engineering degrees anytime and anywhere, part-time or full time, virtually or on campus, or both.

In this paper, we draw from the research streams of online learning and social influence and develop a research model to determine what factors impact student veteran participation in online engineering learning. We test the research model using regression analysis on data from online engineering master's programs from across the United States. Our empirical results reveal for the first time that the number of online engineering program graduates and the number of full time online faculty have positive, significant influences on veteran participation in online engineering programs. Through our research, we contribute new insights for engineering programs as they leverage transformative, online learning platforms for accelerating the creation and sharing of knowledge between students, professors, and business. Through these seamless, symbiotic information flows, engineering programs should know how to successfully attract student veterans to their online engineering programs; this study provides such insights.
\end{abstract}




\section{Introduction}

This study draws from past research that shows that online student veterans have a positive impact on online engineering program performance $[1,2]$. In this paper, we examine what factors have a significant impact in attracting student veterans to online engineering programs. This is important since student veterans and engineering programs mutually benefit from each other's engagement. Online engineering programs can be particularly helpful for veterans with post-9/11 GI Bill collegiate education benefits as they transition from military to civilian employment. Now most top online engineering master's programs enable students to receive their degrees $100 \%$ online [3].

From the landmark study by C.A. Cate (2014) "Million Records Project: Research from Student Veterans of America" [4], active duty personnel who are also students typically juggle competing responsibilities and may be forced to place their academics on hold while on field assignments, recovering from injuries, or performing other service-related commitments. The post-9/11 GI Bill has had unequivocal economic and quality of life impacts on the US market and beyond. $36 \%$ of veterans that earn a two year degree online, go on to successfully earn advanced degrees [4]. 64\% of active duty members who initially enroll in online college programs, graduate, and $51 \%$ of student veterans who initially enroll go on to graduate [4]. Most student veterans are supported by the Post-9/11 GI Bill for collegiate education, as they transition into civilian careers from service roles. Online engineering programs free students of temporal and geographic constraints by enabling them to take classes anytime and anywhere with little or no transportation costs. Online educational programs have emerged as an innovative alternative to traditional off-line, face-to-face programs in "brick and mortar" classrooms on college campuses. This study brings these developments together to answer the following research question:

What factors have a positive impact on student veteran and active duty member enrollment in online graduate engineering programs?

To answer this question, we develop a research model from hypotheses drawing from the literature. From the literature streams of online learning and social influence, we examine the social influence of online program graduates on online student enrollment who served or are serving in the armed forces of the United States (Figure 1). The model is then tested using secondary data from the top online engineering programs in the United States [5]. The findings suggest that the number of fulltime online faculty as well as the graduation rate have significant influences on student veteran and active duty member participation in online graduate engineering programs. This paper concludes with implications for engineering education and recommendations for future research. We next present our literature reviews on online learning and social influence. 


\section{Online Learning}

Online learning is transforming learning for students, by attracting new types of students who live off campus and interact virtually in class. Nearly 6 million students representing $28 \%$ of all students took at least one course online in 2016. 2.85 million students took all their courses online, and another 2.97 million took some of their courses online [6]. The online education phenomenon is immense with an overall year-to-year growth rate of 3.9\% [7].

Past research on online graduate engineering program performance has shown that the number of successful graduates is positively influenced by the enrollment of student veterans as well as by the variety of engineering majors and courses offered [2]. Online engineering students are more likely to graduate when they have more diverse options of curriculum to choose from, based on what they want and need [8]. Research also shows that the number of part-time online instructors also has a positive impact on online engineering program graduation rates [1]. Hence, hiring more online part-time faculty should enable programs to teach a greater variety of online courses which, in turn, will likely have a positive influence on graduation rates.

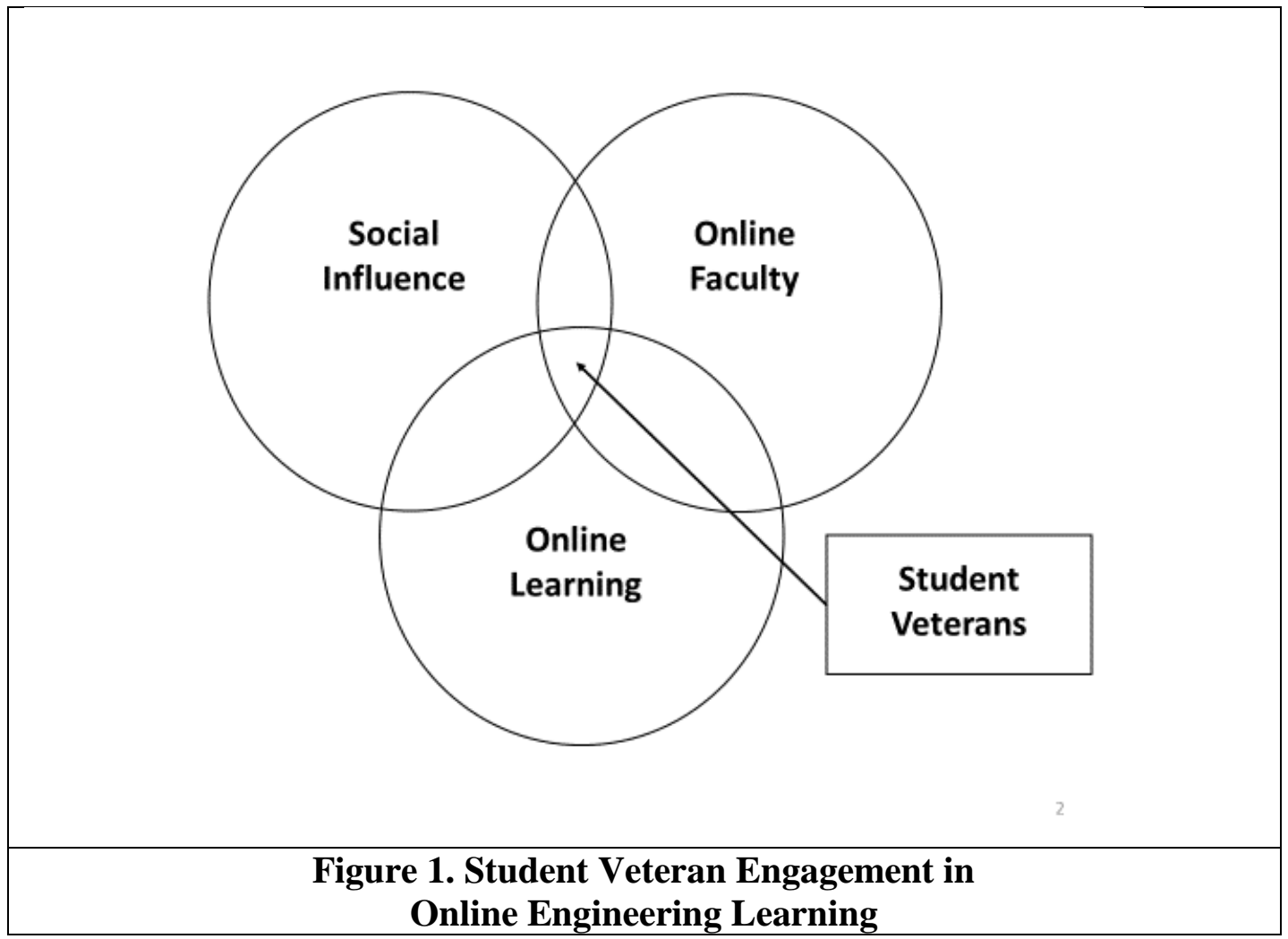

Online educational programs support student-centered learning pedagogy where learning shifts from top-down to bottom-up. Student use of online education programs has become seamless because these online platforms are not only easy to use and useful, but they also enable students to interact with instructors as well as peers and the course content [7]. This transformation has made it easier to gauge active vs. passive students. From social learning theory, human behavior is described as an ongoing interaction among cognitive, behavioral, and environmental factors [9]. Learning new ways to learn would take much more effort if it was limited to one's own autonomous actions [10]. Hence, through its own wide-spread acceptance and use, it has become easier for new students to adopt online learning as their means for graduate education. 
With the rise of online education programs, some engineering programs are moving towards "upside-down" classes emphasizing peer-led, student-centric, experiential learning [3]. Such active-learning approaches have helped increase confidence, intellectual curiosity, and teambuilding among students and should, therefore, contribute to successful graduation outcomes [11]. Many students, especially graduate students who work full or part-time in the military or as civilians, want more than traditional lectures at the same time and place.

Traditional lectures are based primarily on one-way information flows from professor down to the students in the classroom. In the traditional classroom, it can be difficult to gauge if students are active or passive participants [7].

Most traditional engineering programs are now also online offering a greater variety of majors and courses to complement and supplement the traditional, physical college campus classroom. Research shows that online learning can be as effective as offline learning for students [12]. In the past, however, Web-based multimedia learning was less than seamless due to technical constraints including the unstructured nature of the Web. Often, there was too much emphasis on learning the technology and not the content of the course [13]. Online learning has since become more seamless as the enabling technologies have become more sophisticated and less expensive. Online students can now easily receive course information and share their knowledge $24 \times 7$. In the online learning literature, the determinants of course structure, interaction, and selfmotivation have been among the factors determined significant for perceived student satisfaction [14]. Hence, in the context of online graduate engineering education, a greater variety of engineering majors and online courses should enhance course structure, interaction, and selfmotivation leading to greater utility and satisfaction for online students.

Online engineering educational programs support student-centered learning pedagogy being embraced by engineering schools where learning is shifting from a deductive lecture paradigm (bottom-up) approach, to an inductive self-directed (top-down) learning approach [8]. Online learning has gained in popularity reaching a critical mass of adoption leading to greater diffusion. One learns how to execute new behaviors through the social influence from observing others [9]. We next examine the literature on social influence and how that applies to the use of online learning platforms.

\section{Social Influence}

Deutsch and Gerard [15] break down the social influence of group norm between the 1) normative influence and the 2) informational influence. Normative social influence is, "the influence to conform to the positive expectations of another", [15, p. 629]. In the context of IT use, this is where the user feels he or she is obligated to use a new IT system that others are using. Normative influence is the "pull" of the individual to conform to his or her perceptions of the wishes of others in using a new system.

Informational influence, on the other hand, is "the influence to accept information obtained from another as evidence about reality" [15, p. 629]. In this situation, the user is influenced to use a new system by directly observing the benefits of information from the adoption and use of that system by others [15]. Informational influence is the self-driven "push" by the user to attain the same perceived informational benefits. From social information processing models, an actor's 
perceptions of the benefits of using new systems are shaped by the actor's social networks [16]. Positive communication about the use of a new IT system such as online learning can positively influence an individual in the same social networks to use the new IT system [17]. Informational influence also draws from the theory of social learning in that the individual learns how to use new systems from the experience of others, thus avoiding the opportunity costs of trying to learn on his or her own [9].

Lewis et al. [18] identify three factors of individual beliefs for using a new IT system: 1) individual, 2) institutional, and 3) social norm, which, in turn, are related to either informational or normative social influence. The individual factor includes computer self-efficacy that draws from social cognitive theory in that the informational influence from watching others perform a behavior, impacts the individual into thinking that he or she can also successfully perform that behavior [19]. The institutional factor includes engineering school commitment to a new IT system such as an online learning platform which can help legitimize the perception of usefulness for students [18].

Informational social influence can be manifest through informational cascades. Bikhchandani et al.[20] describe informational cascades as sequential situations where it is optimal for the individual to follow the observed behaviors of others ahead of him or her, instead of autonomously relying just on one's own, privately-held information. Deutsch and Gerard [15] empirically show that the more uncertain an individual is with how correct his or her own judgment is, the more likely he or she will use informational social influence when making decisions. In politics, information cascades can occur during elections when individual voters are influenced by the political momentum created by earlier voters. In finance, the initial bid in a corporate takeover is often followed by other competing bids despite increases in cost compared to the initial bid [20].

In addition to information cascades, informational social influence can be manifest through the internalization that occurs when an individual starts believing that a new IT system is really useful, because it is endorsed as being so by his or her peers or by a boss $[15,21]$. Hence, internalization can be a means by which the subjective norm indirectly affects the perceived usefulness intention for using a new IT system. Internalization, from informational influence, can result in both voluntary and mandatory contexts of IT use [21]. This is in contrast to the subjective norm that can directly affect intention to use out of compliance to someone who is considered important to the user (e.g. who can reward or punish), without perceiving the new IT system of being useful [21]. In this case, compliance from subjective norm can occur in mandatory, but not in voluntary contexts $[21,22]$.

In social circles, the impact of peer pressure is demonstrated by followers, especially those with less knowledge or experience, who prefer to conform to the decisions of their peers [20]. Hence, the social influence for using a new IT system can be due to knowledge received from individual social networks, supported by social information processing theory [23]. If an individual observes that others in his or her social network believe that a technology is useful, it is likely that the individual will also believe so [18]. This is tested in our study by considering the social influence of online program graduates on online student veteran participation. We next describe the design, data sample, and statistical analysis technique of our research. 


\section{Research Design, Data Sample and Statistical Analysis Technique}

This quantitative, empirical paper uses secondary data for testing a theoretical research model formed from the hypotheses. The impact of the social influence of online graduates and full time online faculty on student veteran participation are examined. We test our research model using data from the top 65 online programs in the United States as ranked by U.S. News \& World Report [24]. The unit of analysis is online graduate engineering programs in the United States. The statistical analysis technique used to test the research model is linear regression via SPSS software. This research takes a positivist, philosophical approach, developing hypotheses by extending previous online learning and social influence research streams. We next discuss our hypothesis and research model.

\section{Hypotheses Development and Research Model}

The hypotheses for investigating the impact of the social influence of online graduates and fulltime online faculty on online veteran enrollment are next developed. Social norm factors that Lewis et al. [18] use include the normative influences from various groups including supervisors, senior leaders, professional peers, and informal circles. In the context of online learning in this study, this equates to the influences of fulltime online faculty as well as online student graduates who successfully use the online learning platform.

Social Influence research shows that if an individual observes that others in his or her social network believe that a technology is useful, it is likely that the individual will also believe so [18]. Research also shows that distance learners, like veterans, are more likely to be older with families and full-time jobs compared to traditional students living on campus [12]. Online learning research also shows that these non-traditional students are likely to have the same or even greater determination in accomplishing their academic goals [12]. Student veterans are often older and have more worldly experiences in a disciplined and goal setting environment compared to many of their civilian counterparts. We argue that the social influence of online graduates in online engineering programs should have a positive influence for engineering school student veteran participation. This leads us to our first hypothesis shown in our research model in Figure 2:

Hypothesis 1: The number of online engineering program graduates will have a positive impact on online student veteran or active service member participation in online learning.

Among the factors that enhance academic performance, is the material reputation and prestige of the institutional as a proxy of its full-time faculty, signifying a dedication to the pursuit of excellence [25]. In a reciprocating relationship, the reputation of the academic institution is enhanced by the quantity and quality of graduates produced; and in turn, graduating students garner prestige for having successfully received their diploma from the institution. This cycle is further bolstered by up/down-stream constituents such as legal and credentialing organizations, guidance counselors, institutional donors, research bodies, corporate trustees, private/public industry recruiters, and more [25]. To achieve and sustain enhanced institutional status requires critical financial operating resources. In the face of increasing online admissions and lack of 
strategic readiness, academic administrators are driving a decrease in part-time faculty to student ratios, which can have the side effect of increasing the full-time faculty to student ratios [25].

Quality student-teacher interactions have been shown to motivate students towards achieving academic goals in technology mediated learning environments [26, 27]. With increasing access to online education options which enable student-teacher interactions, scholars and academic leaders expect enrollment rates to steadily rise. Surely, this will also benefit those active duty and other non-traditional students in their post-secondary education pursuits. In preparation, academic institutions will need to further design online programs to support this increase in online enrollments with dedicated, full time online faculty.

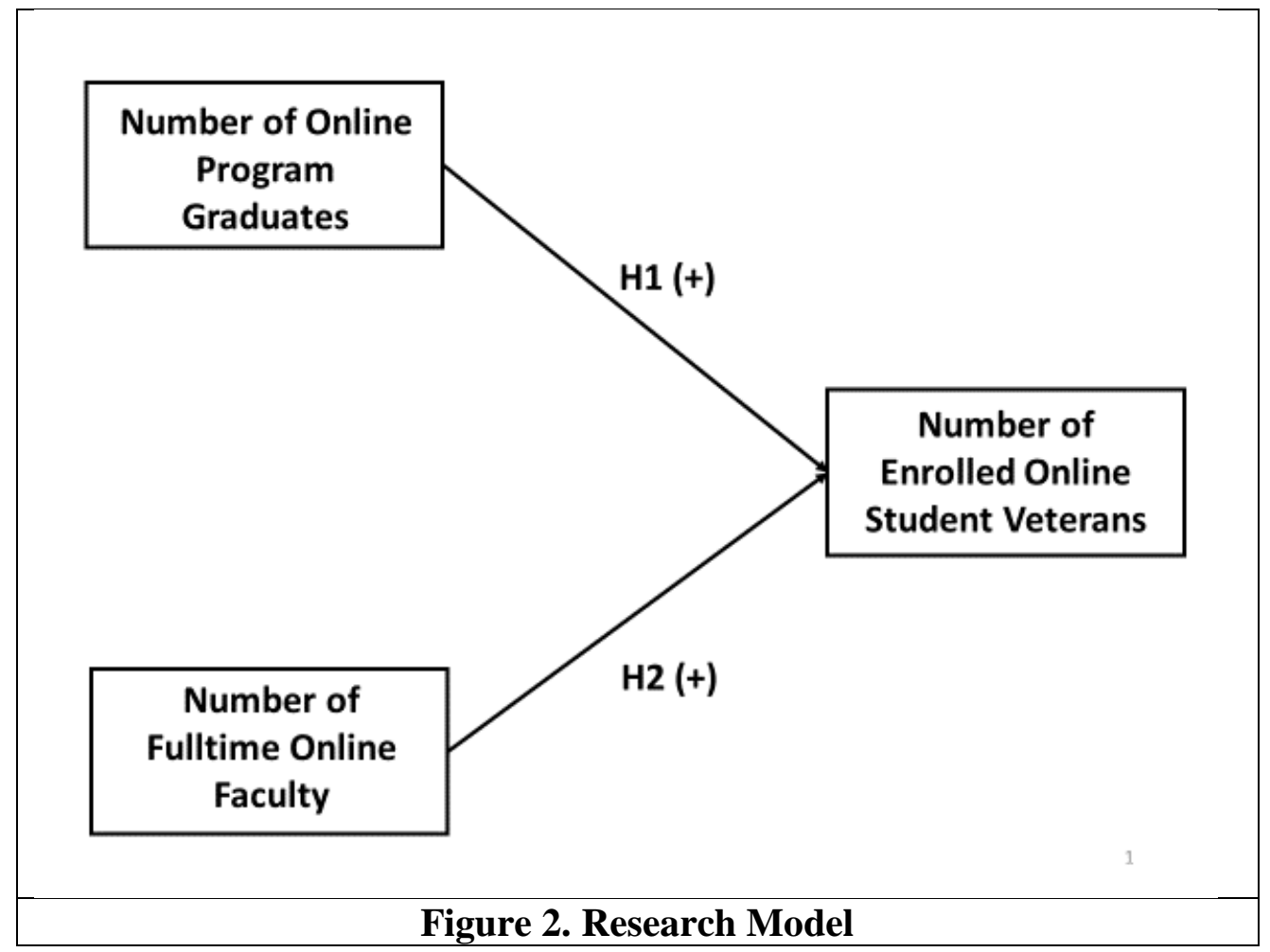

In business and industry today, changing organizational structures are creating greater demand for interdisciplinary engineering education to prepare students who are not only specialized, but are also able to interact with different types of engineers such as those who are electrical, computer, and mechanical. Engineers today need not only depth, but also a breadth of skills to work with experts from multiple specialties for a multidisciplinary approach. Engineering students can save money by enrolling in online interdisciplinary, customizable master's degree programs [3]. Hence, engineering schools that offer greater varieties of educational content for students taught by a greater number of dedicated, full time faculty members should attract a greater number of student veterans who enroll. This leads us to our second hypotheses shown in our research model in Figure 2:

Hypothesis 2: The number of fulltime online faculty will have a positive impact on online student veteran or active service member participation in online learning. 
We next describe the variables and measures used in our research model.

\section{Variables and Measures}

The measures of the variables used in the hypotheses of the research model are defined in Table 1. The variable STUDENT VETERANS is measured by the total number veterans and active service members enrolled in online graduate engineering programs in the school year 2015-2016. The variable ONLINE PROGRAM GRADUATES is measured by the total number of students who graduated from online graduate engineering programs in the same period. The U.S. Department of Veterans Affairs recognizes that student veteran completion rate in terms of degree attainment is the best way to measure college success; enrollment rates are limited to measuring who enters but not graduates from college programs [28]. Hence, the number of online program graduates can be a proxy for measuring online graduate engineering program success.

\begin{tabular}{|r|c|}
\hline \multicolumn{2}{|c|}{ Table 1. Variables \& Measures } \\
\hline Variables & Measures \\
\hline STUDENT VETERANS & Number of Online Graduate Engineering School \\
& Students who are Veterans or \\
ONLINE PROGRAM & Active Service Members per Capita \\
GRADUATES & Number of Online Graduate Engineering School \\
\hline FULLTIME ONLINE FACULTY & Sumber of Fulltime Online Faculty in Graduate \\
\hline
\end{tabular}

The variables are next designated in Table 2 as dependent or independent variables for the research model. STUDENT VETERANS is the dependent variable and the other two variables OLINE PROGRAM GRADUATES and FULLTIME ONLINE FACULTY are independent. All three variables are normalized by dividing by the total number online graduate engineering program students that are enrolled in the respective programs.

\begin{tabular}{|c|c|}
\hline \multicolumn{2}{|c|}{ Table 2. Variable Designations } \\
\hline Variables & Designations \\
\hline STUDENT VETERANS & Dependent \\
\hline ONLINE PROGRAM GRADUATES & Independent \\
\hline FULLTIME ONLINE FACULTY & Independent \\
\hline
\end{tabular}

We next present our analysis and results.

\section{Analysis and Results}

The descriptive statistics are shown in Table 3. The average total number of online graduate engineering school students that graduated (2015-2016) in these programs averages 69.8, ranging from 0 to 623. The average number of veterans or active duty members in these programs is 22 , ranging from 0 to 267 . The average number of fulltime online faculty is 32.6 , ranging from 2 to 141. 


\begin{tabular}{|c|c|c|c|c|c|c|}
\hline \multicolumn{7}{|c|}{ Table 3. Descriptive Statistics } \\
\hline & \multicolumn{2}{|c|}{$\begin{array}{c}\text { Number of Veterans or } \\
\text { Active Service } \\
\text { Members }\end{array}$} & \multicolumn{2}{|c|}{$\begin{array}{l}\text { Number Fulltime } \\
\text { Online Faculty }\end{array}$} & \multicolumn{2}{|c|}{$\begin{array}{l}\text { Total Program } \\
\text { Graduates } \\
(\mathbf{2 0 1 5 - 2 0 1 6 )}\end{array}$} \\
\hline & \multicolumn{2}{|c|}{$(n=65)$} & \multicolumn{2}{|c|}{$(n=65)$} & \multicolumn{2}{|c|}{$(n=65)$} \\
\hline Mean & \multicolumn{2}{|c|}{22} & \multicolumn{2}{|c|}{32.6} & \multicolumn{2}{|c|}{69.8} \\
\hline $\begin{array}{l}\text { Standard } \\
\text { Deviation }\end{array}$ & \multicolumn{2}{|c|}{38.2} & \multicolumn{2}{|c|}{34.6} & \multicolumn{2}{|c|}{102.3} \\
\hline Minimum & \multicolumn{2}{|c|}{0} & \multicolumn{2}{|r|}{2} & \multicolumn{2}{|c|}{0} \\
\hline Maximum & \multicolumn{2}{|c|}{267} & \multicolumn{2}{|c|}{141} & \multicolumn{2}{|c|}{623} \\
\hline \multirow{6}{*}{ Frequency } & $<=5$ & $23(35.4 \%)$ & $<=10$ & $23(35.4 \%)$ & $<=15$ & $17(26.2 \%)$ \\
\hline & 10 & $7(10.8 \%)$ & 20 & $10(15.4 \%)$ & 30 & $11(16.9 \%)$ \\
\hline & 15 & $4(6.2 \%)$ & 30 & $9(13.8 \%)$ & 45 & $8(12.3 \%)$ \\
\hline & 20 & $3(4.6 \%)$ & 40 & $5(7.7 \%)$ & 60 & $7(10.8 \%)$ \\
\hline & 25 & $16(24.6 \%)$ & 50 & $5(7.7 \%)$ & 75 & $5(7.7 \%)$ \\
\hline & $>=26$ & $12(18.5 \%)$ & $>51$ & $13(20.0 \%)$ & $>=76$ & $17(26.2 \%)$ \\
\hline
\end{tabular}

Our research model analyzes the impact of ONLINE PROGRAM GRADUATES and FULLTIME ONLINE FACULTY on STUDENT VETERANS (including active service members) enrollment in online graduate engineering programs. The theoretical model developed from the hypotheses is as follows:

\section{ONLINE PROGRAM GRADUATES + FULLTIME ONLINE FACULTY = STUDENT VETERANS}

Regressions on the raw scores $(\mathrm{p}<.10, \mathrm{R} 2=.348)$ were first run followed by regressions on the ratios of the raw scores $(\mathrm{p}<.01, \mathrm{R} 2=.359)$. These were followed by regressions on the Z-scores of the raw scores $(\mathrm{p}<.10, \mathrm{R} 2=.348)$ and finally $\mathrm{Z}$-scores of the ratios of the raw scores $(\mathrm{p}<.01$, $\mathrm{R} 2=.360$ ). The results of this last model yielded the highest significance with the best overall fit as summarized in Table 4. Correcting for generalization bias, the regression model adj. $\mathrm{R} 2=.360$ indicates a large effect size and a good level of prediction [29]. Moreover, the independent variables explain $36.0 \%$ of the variability of the model's dependent variable. The overall results of the model show that the numbers of online program graduates and fulltime online faculty have positive impacts on the number of student veteran and active duty members that are enrolled in online graduate engineering programs.

\begin{tabular}{|c|c|c|c|}
\hline \multicolumn{4}{|c|}{ Table 4. Summary of Multiple Regression Analysis } \\
\hline VARIABLES & B & $\mathbf{S E}_{B}$ & $\boldsymbol{\beta}$ \\
\hline Intercept & 7.15E-07 & 0.099 & \\
\hline FULLTIME ONLINE FACULTY & 0.289 & 0.101 & $.289 * *$ \\
\hline ONLINE PROGRAM GRADUATES & 0.498 & 0.101 & $.498 * * *$ \\
\hline
\end{tabular}


Drawing from the results shown in Table 4, the equation becomes: STUDENT VETERANS = $0.0000007154+(.289 \times$ FULLTIME ONLINE FACULTY $)+(.498 \times$ ONLINE PROGRAM GRADUATES).

Both the coefficients of ONLINE PROGRAM GRADUATES ( $\mathrm{p}<0.001)$ and FULLTIME ONLINE FACULTY $(\mathrm{p}<0.01)$ are found to be positive and significant thereby providing evidence of significant support for hypotheses $\mathrm{H} 1$ and $\mathrm{H} 2$. This means that the number of online graduates, followed by the number of fulltime faculty, lead to higher student veteran enrollment. These findings based on the testing of our research model can be applied by engineering schools for assessing their own online engineering program veteran student recruiting strategies. We next discuss implications and future research.

One outlier was removed and there is independence of residuals, as assessed by a Durbin-Watson statistic of 1.910. Partial regression plots show a linear relationship that is also homoscedastic. Correlation coefficients and Tolerance/VIF values revealed no model collinearity issues. The residuals are normally distributed as assessed by P-P Plot.

\section{Implications and Future Research}

In conclusion, this research suggests 1) greater online graduation rates positively effect online veteran enrollment, and that 2) increasing the number of full-time online faculty, can also encourage increased veteran enrollment. Moreover, these results imply that veterans are attracted to online engineering graduate programs that have successful graduation rates led by dedicated fulltime professors teaching online. A larger fulltime online faculty will likely be able to offer a greater variety of majors and courses for student veterans for their own educational and professional needs. Note that having more "fulltime" online professors implies that there are fulltime dedicated resources committed to the graduation success of their online students. These findings may be of great interest to academic institutions that seek to expand their online student veteran enrollment.

This study is important because it empirically identifies for the first time, specific factors that can improve student veteran participation in online graduate engineering programs. The National Science Foundation (NSF) has promoted the assistance of veterans for attaining careers in engineering so they can participate to the Science, Technology, Engineering, and Mathematics (STEM) workforce for the benefit of society [30]. Furthermore, most student veterans are supported by the Post-9/11 GI Bill for collegiate education as they work to help them transition into civilian careers. In 2015, 790,507 veterans received almost $\$ 12$ billion [31]. This is a large college student demographic in the United States receiving substantial education benefits. There is now a need to better understand student veterans as they embrace online learning.

Through our research model, we identify new opportunities for online engineering programs for enrolling a greater number of student veterans and active duty members. However, further research needs to determine what additional factors, influenced by government, universities, and faculty, lead to greater online student veteran participation and graduation success. 


\section{References}

[1] D. M. Schutz, D. Dionne, and Y.-Y. Kim, "Factors Influencing the Rise of Online Learning in Engineering Education," presented at the Spring 2017 Mid-Atlantic American Society of Engineering Education (ASEE) Conference, Morgan State University, Baltimore, Maryland, 2017.

[2] D. M. Schutz, D. Dionne, and Y.-Y. Kim, "The Impact of Veterans and Curriculum Heterogeneity on Online Graduate Engineering Program Performance: An Empirical Study," in 2017 ASEE Annual Conference \& Exposition, The Ohio State University, Columbus, Ohio, 2017, pp. 1-11: American Society for Engineering Education (ASEE).

[3] S. Wasserman, "The Pros and Cons of Online Engineering Masters Degrees," in ENGINEERING.com, ed. Mississauga, Ontario, Canada: ENGINEERING.com, Inc., 2015.

[4] C. A. Cate, "Million Records Project: Research from Student Veterans of America," S. V. o. America, Ed., ed. Washington, DC., 2014.

[5] B. Kelly. (2017) Best Online Graduate Engineering Programs. U.S. News \& World Report. Available: http://www.usnews.com/education/online-education/engineering/rankings

[6] M. Chmura, "Babson Study: Distance Education Enrollment Growth Continues," ed. Wellesley, MA: Babson University, 2016.

[7] I. F. Liu, Chen, M. C., Sun, Y. S., Wible, D., \& Kuo, C. H., "Extending the TAM Model to Explore the Factors that Affect Intention to Use an Online Learning Community," Computers \& Education, vol. 54, no. 2, pp. 600-610, 2010.

[8] R. M. Felder and L. K. Silverman, "Learning and Teaching Styles in Engineering Education " Engineering Education, vol. 78, no. 7, pp. 674-681, 1988.

[9] A. Bandura, Social Learning Theory. New York: General Learning Press, 1977.

[10] D. Schutz, D. Dionne, Yong-Young Kim, "Leveraging Enterprise Mobility Innovation for Knowledge Sharing in the Airline Industry with Implications for Engineering Education," in 2016 ASEE Annual Conference \& Exposition, New Orleans, Louisiana, New Orleans, Louisiana, 2016, pp. 1-14: American Society for Engineering Education (ASEE).

[11] E. C. Johnson, B. A. Robbins, and M. C. Loui, "What Do Students Experience as Peer Leaders of Learning Teams?," Advances in Engineering Education, vol. 4, no. 4, 2015.

[12] J. Lu, Yu, C. S., \& Liu, C. L, "Learning Style, Learning Patterns, and Learning Performance in a WebCTbased MIS Course. Information \& Management," Information \& Management, vol. 40, no. 6, pp. 497-507, 2003.

[13] M. J. Hannafin and H. K. M., "Cognition and Student-Centered, Web-Based Learning: Issues and Implications for Research and Theory," in Learning and Instruction in the Digital Age, J. M. Spector, Ed. New York: Springer, 2009, pp. pp 11-23.

[14] S. B. Eom, Wen, H. J., \& Ashill, N. , "The Determinants of Students' Perceived Learning Outcomes and Satisfaction in University Online Education: An Empirical Investigation.," Decision Sciences Journal of Innovative Education, vol. 4, no. 2, pp. 215-235, 2006.

[15] M. Deutsch and H. B. Gerard, "A Study of Normative and Informational Social Influences upon Individual Judgment," The Journal of Abnormal and Social Psychology, vol. 51, no. 3, p. 629, 1955.

[16] D. J. Brass, J. Galaskiewicz, H. R. Greve, and W. Tsai, "Taking Stock of Networks and Organizations: A Multilevel Perspective," Academy of Management Journal, vol. 47, no. 6, pp. 795-817, 2004.

[17] H. Lou, W. Luo, and D. Strong, "Perceived Critical Mass Effect on Groupware Acceptance," European Journal of Information Systems, vol. 9, no. 2, pp. 91-103, 2000.

[18] W. Lewis, R. Agarwal, and V. Sambamurthy, "Sources of Influence on Beliefs about Information Technology Use: An Empirical Study of Knowledge Workers," MIS Quarterly, vol. 27, no. 4, pp. 657-678, 2003.

[19] A. Bandura, "Self-efficacy: Toward a Unifying Theory of Behavioral Change," Psychological Review, vol. 84, no. 2, pp. 191-215, 1977.

[20] S. Bikhchandani, D. Hirshleifer, and I. Welch, "A Theory of Fads, Fashion, Custom, and Cultural Change as Informational Cascades," The Journal of Political Economy, vol. 100, no. 5, pp. 992-1026, 1992.

[21] V. Venkatesh and F. D. Davis, "A Theoretical Extension of the Technology Acceptance Model: Four Longitudinal Field Studies," Management science, vol. 46, no. 2, pp. 186-204, 2000.

[22] J. Hartwick and H. Barki, "Explaining the Role of User Participation in Information System Use," Management Science, pp. 440-465, 1994. 
[23] J. Fulk, "Social Construction of Communication Technology," The Academy of Management Journal, vol. 36, no. 5, pp. 921-950, 1993.

[24] B. Kelly. (2016) Best Online Graduate Engineering Programs. U.S. News \& World Report.

[25] P. Cyrenne and H. Grant, "University Decision Making and Prestige: An Empirical Study," Economics of Education Review, vol. 28, no. 2, pp. 237-248, 2009.

[26] L. Deckers, Motivation: Biological, Psychological, and Environmental (London). Psychology Press Ltd, 2015.

[27] H. Kanuka and T. Anderson, "Using Constructivism in Technology-mediated Learning: Constructing Order Out of the Chaos in the Literature," Radical Pedagogy, 1999.

[28] L. Sander, "Veterans' Graduation Rates Are Focus of New Partnership," in The Chronicle of Higher Education, ed. Washington D.C.: The Chronicle of Higher Education Inc., 2013.

[29] J. Cohen, Statistical power analysis for the behavioral sciences. Lawrence Erlbaum, 1988.

[30] N. Fortenberry, "Transitioning Veterans to Engineering-Related Careers: Next Steps," M. Matthews, Ed., ed. Washington D.C.: American Society for Engineering Education (ASEE), 2014.

[31] B. McDonald, "Benefits for Veterans Education " in Veterans Benefits Association, U. S. D. o. V. Affairs, Ed., ed. Washington D.C., 2016, pp. 1-16. 